\title{
PROBİYOTİK KÜLTÜRLERİN MİKROENKAPSÜLASYONUNDA KULLANILAN FARKLI KAPLAMA MATERYALLERİ VE YÖNTEMLER
}

\author{
Burak Geniş ${ }^{*}$, Yasin Tuncer \\ Süleyman Demirel Üniversitesi, Mühendislik Fakültesi, Gida Mühendisliği Bölümü, Isparta, Türkiye
}

Geliş / Received: 30.05.2019; Kabul / Accepted: 31.10.2019; Online bask1 / Published online: 27.11.2019

Geniş, B., Tuncer, Y. (2019). Probiyotik kültürlerin mikroenkapsülasyonunda kullanılan farklı kaplama materyalleri ve yöntemler. GID $A$ (2019) 44 (6) 1222-1236 doi: 10.15237/gida.GD19087

Genis, B., Tuncer, Y. (2019). Different coating materials and methods used in microencapsulation of probiotic cultures. GIDA (2019) 44 (6) 1222-1236 doi: 10.15237/gida.GD19087

ÖZ

Fonksiyonel gıdaların üretiminde kullanılan probiyotik bakteriler, insan sağlığını destekleme ve sürdürmede önemli rol oynayabilmektedir. Probiyotik kültürlerin bu ürünlerde sağladıkları avantajların yanı sıra kullanımlarını sınırlandıran bazı faktörler de bulunmaktadır. Probiyotik kültürlerin gıda ortamında çevresel koşullardan etkilenmeleri ve canllıklarını uzun süre koruyamamaları en önemli dezavantajlarıdır. Son yıllarda, probiyotik kültürlere olumsuz çevresel koşullara karşı koymaları için fiziksel bir bariyer oluşturulması sıklıkla uygulanan bir yöntem haline gelmiştir. Probiyotik kültürlerin korunmasına yönelik mikroenkapsülasyon yöntemleri, bu mikroorganizmaların gıda ürünlerinde ve gastrointestinal sistemde canlı kalma oranlarını büyük ölçüde arttırmaktadır. Ek olarak mikroenkapsülasyon probiyotik kültürlerin istenilen zamanda ve bölgede kontrollü salınımını sağlayarak kültürün etkinliğini güçlendirmektedir. Bu derlemede, probiyotik kültürlerin mikroenkapsülasyonunda kullanılan kaplama materyalleri ve mikroenkapsülasyon yöntemleri özetlenmiştir.

Anahtar kelimeler: Probiyotik kültür, mikroenkapsülasyon, kaplama materyali, mikroenkapsülasyon yöntemleri

\section{DIFFERENT COATING MATERIALS AND METHODS USED IN MICROENCAPSULATION OF PROBIOTIC CULTURES}

\begin{abstract}
Probiotic bacteria used in the production of functional foods may play an important role in the promote and maintenance of human health. In addition to the provide advantages of probiotic cultures in these products, there are some factors that limit their use. The most important disadvantages of probiotic cultures that they are affected by enviromental conditions in food and can not maintain their viability for a long time. In recent years, the creation of physical barrier to counteract adverse enviromental conditions of probiotic cultures has become a frequently applied method. Microencapsulation methods for protection of probiotic cultures greatly increase their survival in food products and gastrointestinal tract. In addition, microencapsulation enhances the efficiency of the culture by providing controlled release of probiotic cultures at the desired time and site. In this review, coating materials and microencapsulation methods used for microencapsulation of probiotic cultures were summarized.
\end{abstract}

Keywords: Probiotic culture, microencapsulation, coating material, microencapsulation techniques

\footnotetext{
* Yazışmalardan sorumlu yazar / Corresponding author:

$\triangle$ burakgenis@hotmail.com @ (+90) 2462111713

岛 (+90) 2462370437
} 


\section{GİRIŞ}

Günümüz toplumlarında tüketicilerin sağlıklı gıda tüketim bilincinin artması, tüketim tercihlerinin ve davranışlarının değişmesine neden olmaktadır (Varhan ve Koç, 2018). Gün geçtikçe birçok tüketici gidaların sadece beslenme amaciyla tüketilmesinin yerine, daha doğal gidalar ile beslenerek gıda kaynaklı hastalıklara karşı korunmak ve güvenli gidalara erişebilmeyi arzu etmektedir (Đorđević vd., 2015; Turasan vd., 2015). Değissen üretim koşulları, tüketici talepleri ve bu alanda artan pazar doğrultusunda gida endüstrisinde güvenli ve sağllklı g1da üretimi önem kazanmıştır (Rocha vd., 2017; Varhan ve Koç, 2018). Bu bağlamda gida endüstrisi ve araştırmalar, sağlık üzerine olumlu etki gösteren doğal bileşenler ile takviye edilen gidalara yönelmiştir. Bu gidalar genel olarak fonksiyonel gidalar olarak adlandırılmaktadır (Sarao ve Arora, 2017). Fonksiyonel gidalar temel beslenme ihtiyacı için gerekli olan besin bileşenlerini karşılamanın yanında insan metabolizması üzerine olumlu etki göstererek hastalık riskini azaltan gidalar ya da gida içerisinde bulunan bileşenler olarak tanımlanmaktadır (Altun ve Özcan, 2013). Dünya genelindeki fonksiyonel gıda pazarının büyük bir kısmını, tek veya karışık kültürlerden oluşan antimikrobiyal aktiviteye sahip, ürün kalitesini artırıcı özellik gösteren ve insan sağlığına fayda sağlayan probiyotik kültürlerin kullanımı ile üretilen fonksiyonel gidalar oluşturmaktadır (Soccol vd., 2014; Espitia vd., 2016; Li vd., 2016; Pradeep Prasanna ve Charalampopoulos, 2018; Arepally ve Goswami, 2019). Dünya Sağlik Örgütü (WHO) tarafindan probiyotikler, canlıların sindirim sisteminde yeterli sayıda ve canlılıkta bulunduklarında konak sağlığı üzerine olumlu etkileri olan canlı mikroorganizmalar olarak tanımlanmaktadır (Kumar vd., 2015; Martín vd., 2015; De Prisco ve Mauriello, 2016; Espitia vd., 2016; Arslan-Tontul ve Erbas, 2017; Roshanzamir vd., 2017; Shori, 2017; Pradeep Prasanna ve Charalampopoulos, 2018). Probiyotik bakterilerin konakta fayda sağlayabilmesi için tüketim öncesi üründe minimum $10^{6}-10^{8} \mathrm{kob} / \mathrm{g}$ veya $\mathrm{mL}$ düzeyinde bulunmasının yanı sira düzenli olarak tüketilmesi, patojen ve toksik etki göstermemesi, mide ortamını geçerek hayatta kalması, safra asitlerine karş1 dayanıklı olması, bağırsaklara büyük miktarda ulaşarak kolonileşmesi ve metabolik aktivitesine devam etmesi gerekmektedir (Dianawati vd., 2016; De Prisco vd., 2017; Pandey ve Vakil, 2017; Uran vd., 2017; Wang vd., 2019). Bunlarla birlikte probiyotik mikroorganizmaların canlilığ1 üzerine $\mathrm{pH}$, hidrojen peroksit, oksijen, depolama sicaklığ1 gibi faktörlerin de etki gösterdiği bilinmektedir (Martín vd., 2015). Probiyotik kültürlerin gıda endüstrisinde kullanımlarını kısıtlayan bir başka faktör ise proses basamaklarında mikroorganizmanın canlilik oranını etkileyen yöntemler kullanılması ve bu nedenle probiyotik kültürlerin stabilitesini kaybetmesidir (Uran vd., 2017). Günümüzde probiyotik kültürlerin konak sindirim sistemine yerleşmesi ve canlllığını sürdürmesini engelleyebilecek olumsuz etmenlere karşı direnç kazanmaları için farklı yöntemler kullanılmaktadır. $\mathrm{Bu}$ yöntemler arasında asit ve safraya dirençli suşların seçimi, oksijen geçirmeyen ambalajların kullanımı, iki aşamalı fermantasyon, stres adaptasyonu, peptit ve amino asit içeren mikrobesinlerin ilave edilmesi ve mikroenkapsülasyon siklıkla tercih edilmektedir (Martín vd., 2015; Pradeep Prasanna ve Charalampopoulos, 2018). Son yillarda yapilan araştırmalar probiyotik kültürlerin stabilitesi ve konakta sağladıkları fayda oranını arttırmak için mikroenkapsülasyon yönteminin kullanılması üzerine yoğunlaşmıştır (Martín vd., 2015; Dianawati vd., 2016; Espitia vd., 2016; Pandey ve Vakil, 2017; Kavitake vd., 2018; Pradeep Prasanna ve Charalampopoulos, 2018; Arepally ve Goswami, 2019; Singh vd., 2019)

\section{Mikroenkapsülasyon}

Enkapsülayon, bir maddenin dış etkenlerden korunması ve istenilen koşullarda açığa çıkabilmesi için özel şartlar altında nano $(\leq 0,2$ $\mu \mathrm{m})$, mikro $(0,2-5000 \mu \mathrm{m})$ ve makro $(\geq 5000 \mu \mathrm{m})$ boyutlardaki bir koruyucu kaplama maddesi ile kaplanması veya bir taşıyıcı materyale bağlanması prensibine dayalı bir yöntemdir (Çakır, 2006; Paulo ve Santos, 2017; Roshanzamir vd., 2017; Sarao ve Arora, 2017; Kavitake vd., 2018). Enkapsülasyon işlemi farklı yöntemler kullanılarak uygulansa da temel olarak üç aşamadan oluşmaktadır. Birinci aşamada biyoaktif 
bileşen katı veya sıvı matriks içerisine dâhil edilir. İkinci aşamada sıvı matriks dispersiyonu sağlanır ve son aşamada fiziksel (buharlaştırma, katılaştırma vb.), kimyasal (polimerizasyon) veya fizikokimyasal (jelifikasyon) bir yöntemle stabilize edilerek enkapsülasyon işlemi gerçekleştirilir (Sarao ve Arora, 2017). Enkapsülasyon işlemi uygulanan aktif madde çekirdek materyal (core material) olarak tanımlanır ve çözünmüş veya disperse olmuş sıvı veya katı yapıda olabilir. Ana maddenin içinde dağıldığı koruyucu matriks yapısı için kaplama, kapsül, duvar veya kabuk gibi benzer tanımlar kullanilır (Dianawati vd., 2016; Sarao ve Arora, 2017). Mikroenkapsülasyon işlemi sonrası meydana gelen mikrokapsüllerin genellikle çaplar1 0.01 ve $1.000 \mu \mathrm{m}$ aralığında iken, aktif malzemenin üzerini kaplayan duvar kalınlı̆g ise 0.5-150 $\mu \mathrm{m}$ olmaktadır (Peanparkdee vd., 2016). Mikroenkapsülasyon yöntemi sonucu elde edilen ürünler mikropartiküller olarak bilinmektedir. Mikropartiküller için kullanılan mikroküre ve mikrokapsül terimleri eşanlamlı gibi gözükse de, içyapıları ve morfolojileri sayesinde farklılık göstermektedir (Paulo ve Santos, 2017). Çekirdek materyal, duvar materyali ve mikroenkapsülasyon tekniğinin çeşitli özelliklerine göre farklı partiküller elde edilebilmektedir. Morfolojilerine göre mikrokapsüller tek çekirdekli (mononuclear), çok çekirdekli (poly/multinuclear), matriks (matrix), çok katlı (multi-wall) ve düzensiz (irregular) olarak tanimlanabilmektedir (Peanparkdee vd., 2016). Mikroenkapsülasyon yöntemi günümüzde ilaç (\%68), gida (\%13), kozmetik (\%8), tekstil (\%5), biyomedikal (\%3), tarım (\%2) ve elektronik (\%1) gibi farklı sanayi dallarında siklıkla kullanilmaktadır (Paulo ve Santos, 2017). Enkapsülasyon yönteminin farklı endüstri alanlarındaki temel kullanım amaçlarından bazıları; istenmeyen bileşiklerin uzaklaştırılması, sıv1 bileşiğin katı forma dönüştürülmesi, çevresel kaynaklı olumsuzlukların minimize edilmesi, mikroenkapsülasyon işlemi ile üründe tat ve kokunun maskelenmesi, aktif bileşiklerin uçucu özelliklerinin baskılanması, mikroenkapsüle ürünün hedeflenen zamanda kontrollü olarak salınımının gerçekleştirilmesi, kaplanmış çekirdek materyalinin farklı bileşenler ile etkileşime girmesinin engellenmesi, ürünlerin daha rahat taşınması ve uzun süreli depolanması gibi fayda sağlayacak özelliklerin elde edilmesidir (Sagis, 2015; Wani vd., 2016). Mikroenkapsülasyon uygulamalarının başarısı, koruma altına alınacak aktif materyalin hangi teknik ve kaplama materyali kullanılarak enkapsüle edileceği ile ilgilidir. Günümüzde laktik asit bakterileri ve probiyotik mikroorganizmaların mikroenkapsülasyonunda farklı yapı ve özellikler taşıan aljinatlar, peynir altı suyu proteinleri, nişasta, karregenan, selüloz asetat fitalat (CAP), kitosan, jellan ve ksantan gam, jelatin ve nohut proteinleri gibi bazı kaplama materyalleri kullanılmaktadır. Mikroenkapsülasyon işleminde bu kaplama materyalleri ekstrüzyon, emülsiyon, akışkan yatak, rennet ile jelleştirilmiş protein, dondurarak kurutma, püskürtmeli kurutma, hibridizasyon, çarpişmalı aerosol teknolojisi ve elektrodöndürme (elektrospinning) yöntemleri ile uygulanabilmektedir (Martín vd., 2015; Kavitake vd., 2018). Laktik asit bakterileri ve probiyotik bakterilerin enkapsülasyonunda kullanılan kaplama materyalleri ve enkapsülasyon yöntemleri Çizelge 1'de verilmiştir.

\section{Mikroenkapsülasyonda Kullanılan Kaplama Materyalleri}

Mikroenkapsülasyon işleminin başarılı olabilmesi için ürüne ve kullanılacak tekniğe uygun kaplama materyali seçimi çok önemlidir. Genel olarak tercih edilen kaplama materyalleri toksik olmamalı, GRAS (genel olarak güvenli kabul edilen) özellikte olmalı, kaplama işlemi sırasında kolay işlenebilmeli, inert olmalı, aktif materyal ile uygulama sirasinda ve sonrasinda materyalin özelliğini etkileyecek reaksiyonlara girmemeli ve aktif materyalin stabilitesini arttırmalı, aktif materyali beklenen çevresel etkilerden koruyabilmeli, beklenen zamanda aktif materyalin salınımı için uygun yapıda olmalı ve yüksek maliyete sahip olmamalıdır (Azagheswari vd., 2015; Giro-Paloma vd., 2016; Atak vd., 2017; Başyigit vd., 2017; Suganya ve Anuradha, 2017; Ramani ve Ramani, 2018). Probiyotik kültürlerin mikroenkapsülasyonunda kaplama materyali olarak polisakkarit (aljinat, ksantan gam, kkarragenan, nişasta ve türevleri, vb.), protein (jelatin ve süt proteinleri vb.) ve lipit (süt yağ1, kakao yağ1 ve hidrojene yağ, vb.) bazlı bileşikler 
kullanılmaktadır (Chen vd., 2017). Günümüzde probiyotik kültürlerin mikroenkapsülasyonunda polisakkarit bazlı kaplama materyallerinden aljinatlar, nişasta, karregenan, jellan gam, ksantan gam ve kitosan kullanilirken, protein bazlı kaplama materyallerinden ise peynir alt1 suyu proteinleri, jelatin, nohut proteinleri ve selüloz asetat fitalat gibi bileşikler kullanılabilmektedir (Martín vd., 2015; Chen vd., 2017; Kavitake vd., 2018).

Çizelge 1. Laktik asit bakterileri ve probiyotik bakterilerin enkapsülasyonunda kullanılan kaplama materyalleri ve enkapsülasyon yöntemleri

\begin{tabular}{|c|c|c|c|}
\hline Bakteri & Enkapsülasyon yöntemi & $\begin{array}{l}\text { Kaplama } \\
\text { materyalleri }\end{array}$ & Kaynak \\
\hline $\begin{array}{l}\text { Lactobacillus acidophillus (La-05) } \\
\text { Bifidobacterium lactis (Bb-12) }\end{array}$ & Püskürtmeli kurutma & Selüloz asetat fitalat & $\begin{array}{l}\text { Fávaro-Trindade } \\
\text { ve Grosso (2002) }\end{array}$ \\
\hline $\begin{array}{l}\text { Bifidocaterium brevi } \mathrm{R} 070 \\
\text { Bifidobacterium longum } \mathrm{R} 023\end{array}$ & Püskürtmeli kurutma & $\begin{array}{l}\text { Peynir alt1 suyu } \\
\text { proteinleri }\end{array}$ & $\begin{array}{l}\text { Picot ve Lacroix } \\
(2004)\end{array}$ \\
\hline $\begin{array}{l}\text { Lactobacillus acidophillus } \\
\text { Bifidobacterium lactis }\end{array}$ & Emülsiyon & $\begin{array}{l}\text { Sodyum aljinat ve } \\
\text { modifiye nişasta }\end{array}$ & $\begin{array}{l}\text { Kailasapathy } \\
(2006)\end{array}$ \\
\hline $\begin{array}{ll}\text { Lactobacillus } & \text { rhamnosus } \\
\text { ATCC53103ТМ } & \end{array}$ & Ekstrüzyon & $\begin{array}{l}\text { Ksantan gam-jellan } \\
\text { gam }\end{array}$ & $\begin{array}{l}\text { Jiménez-Pranteda } \\
\text { vd. (2009) }\end{array}$ \\
\hline $\begin{array}{l}\text { Bifidobacterium longum ATCC } \\
\text { BAA-999TM }\end{array}$ & & & \\
\hline $\begin{array}{l}\text { Lactobacillus plantarum 299v } \\
\text { Lactobacillus plantarum } 800 \mathrm{y}\end{array}$ & Liyofilizasyon & $\begin{array}{l}\text { Sodyum aljinat ve } \\
\text { peynir alt1 suyu }\end{array}$ & Gbassi vd. (2010) \\
\hline $\begin{array}{l}\text { Lactobacillus plantarum CIP } \\
\text { A159 }\end{array}$ & & proteinleri & \\
\hline Lactobacillus rhamnosus GG & Ekstrüzyon & $\begin{array}{l}\text { Peynir alt1 suyu } \\
\text { proteinleri }\end{array}$ & $\begin{array}{l}\text { Doherty vd. } \\
(2012)\end{array}$ \\
\hline Saccharomyces boulardi & Püskürtmeli kurutma & $\begin{array}{l}\text { Jelatin, peynir alt1 } \\
\text { suyu protein } \\
\text { konsatresi, modifiye } \\
\text { nişasta, } \\
\text { maltodekstrin, } \\
\text { bezelye proteini, } \\
\text { gam Arabik }\end{array}$ & Arslan vd. (2015) \\
\hline Lactobacillus reuteri DSM17938 & Vibrasyon & Kitosan-aljinat & $\begin{array}{l}\text { De Prisco vd. } \\
(2015)\end{array}$ \\
\hline Bifidobacterium adolescentis & Emülsiyon & $\begin{array}{l}\text { Nohut proteini- } \\
\text { aljinat }\end{array}$ & Wang vd. (2014) \\
\hline Lactobacillus plantarum 299v & Dondurarak kurutma & Misır nişastas1 & Li vd. (2016) \\
\hline $\begin{array}{l}\text { Lactobacillus acidophilus } \\
\text { ATCC4356 }\end{array}$ & Akışkan yatak & $\begin{array}{l}\text { Sodyum aljinat- } \\
\text { karragenan }\end{array}$ & Afzaal vd. (2018) \\
\hline $\begin{array}{l}\text { L. lactis subsp cremoris MG1363 } \\
\text { (pExu: } m \text { Cherry) }\end{array}$ & Ekstrüzyon & Sodyum aljinat & $\begin{array}{l}\text { Coelho-Rocha } \\
\text { vd. (2018) }\end{array}$ \\
\hline
\end{tabular}

\section{Polisakkarit Bazlı Kaplama Materyalleri} Aljinatlar

Aljinatlar farklı türlerdeki alglerin hücre duvarlarından eksrtakte edilen, L-guluronik asit ve D-mannuronik asit olmak üzere iki monomerden oluşan doğrusal heteropolisakkaritlerdir (Martín vd., 2015; Wani vd., 2016; Sarao ve Arora, 2017; Albadran vd., 2018). Mikroenkapsülasyon işleminde destek malzeme olarak kullanılan aljinatların; toksik özellik göstermemesi, 
ekonomik ve kolay bulunur olmas1, yüksek stabiliteye sahip jeller oluşturmas1, alkali tampon çözeltide kolaylıkla ortaya çıkması ve kalsiyum klorür ile probiyotik bakteriler gibi hassas materyallerin kaplanmasinda hafif matriksler oluşturması gibi avantajları bulunmaktadır (Gökbulut ve Öztürk, 2018; Ramani ve Ramani, 2018). Fakat aljinatların tek başlarına asit ortama karşı duyarlı olması, çevresel faktörlerden etkilenerek koruyucu özelliğinin azalmas1, gözenekli boncuk yüzeyi oluşması ve büyük ölçekli üretimlere çok uygun olmayışı aljinatların kullanımını kısıtlayan önemli faktörlerdir (Gökbulut ve Öztürk, 2018; Marcial-Coba vd., 2019). Bu dezavantajlarına karșın daha dayanıklı kaplama materyali elde etmek için aljinatlarların kitosan, nişasta, karregenan, pektin veya sentetik polimerler ile birlikte kullanılabileceği belirtilmektedir (Đordevic' vd., 2015). Aljinatlar mikroenkapsülasyon yöntemleri arasında genellikle ekstrüzyon yönteminde kullanılmaktadır (Martín vd., 2015). CoelhoRocha vd. (2018), mCherry floresans proteini kodlayan pExu vektörü taşıyan rekombinant $L$. lactic subsp. lactis MG1363 suşunu geliştirdikleri ve $\% 1$ sodyum alginat kullanarak ekstrüzyon yöntemi ile mikroenkapsüle ettikleri çalışmalarında, enkapsüle edilmiş ve edilmemiş suşlar1 C57BL/6 farelerine ağız yoluyla uygulamışlar ve farklı zamanlarda (0-168 saat) ve farklı bağırsak kısımlarında mCherry protein ekspresyon düzeyini ölçmüşlerdir. Konfokal mikroskobi sonucu enkapsüle suş uygulanan hayvanlarda mCherry protein ekspresyonunun daha fazla olduğu tespit edilmiştir. Araştırmacılar bu sonuçları qRT-PCR ile desteklemişlerdir. Elde edilen sonuçlar, mikroenkapsülasyonun bağırsağın farklı bölümlerine yüksek sayıda canlı hücre ulaşmasında etkili bir yöntem olduğunu göstermiştir.

\section{Nişasta ve Türevleri}

Nişasta çok sayıda $\alpha$-D glikoz biriminlerinin glikozidik bağlar yoluyla birleşmesi sonucu oluşan bir polisakkarittir. Pankreas enzimleri tarafindan ince bağırsakta sindirilemeyen nişasta dirençli nişasta olarak tanımlanmaktadır. Dirençli nişasta sindirilmeden fermente olduğu kalın bağırsağın kolon bölümüne ulaşmaktadır. Dirençli nişastanın bağırsağa ulaşması kalın bağırsakta bakteriyel hücrelerin daha iyi salınmasını sağlamaktadır (Sarao ve Arora, 2017). Bu sebeple dirençli nişasta probiyotik hücrelerin bağırsaklara ulaşmaları için mikroenkapsülasyon yöntemlerinde kaplama materyali olarak kullanılmaktadır (Martín vd., 2015; Li vd., 2016; Sarao ve Arora, 2017; MarcialCoba vd., 2019). Li vd. (2016), doğal ve kısmi hidrolize edilmiş mısır nişastasında dondurarak kurutma yöntemi ile mikroenkapsüle edilmiş probiyotik Lactobacillus plantarum $299 \mathrm{v}$ suşunun asit, safra tuzu ve is uygulamalarında hayatta kalma düzeyini araştırmışlardır. Enzimatik hidroliz ile doğal mısır nişastasında bulunan oyuk ve kanalların büyüdüğü ve böylece probiyotik hücre yükleme kapasitesinin arttı̆̆1 tespit edilmiştir. Yapılan çalışma ile mikroenkapsüle edilmiş probiyotik bakterilerin asit toleranslarının serbest hücrelere göre önemli derecede arttı̆̆1 tespit edilmiştir. Elde edilen sonuçlar poröz misır nişastası granüllerinin yüksek probiyotik yükleme kapasitesi olduğunu ve farklı stres koşullarında serbest hücrelere gelişmiş koruma sağladığını göstermiştir.

\section{Karregenan}

Karregenan kırmızı deniz yosunlarından elde edilen hidrofilik, nötr bir polisakkarit olup, gida endüstirisinde katkı maddesi olarak kullanılan doğal bir polimerdir. Karregenanlar genellikle sıcak alkali özütleme işlemi ile deniz yosunu hücrelerinden elde edilmektedir (Martín vd., 2015; Chakraborty, 2017). Karregenan kokuların ve aramoların stabilitesine olumlu katkıda bulunması nedeni ile gida ve kozmetik formülasyonlarında s1klikla kullanılmaktadır (Chakraborty, 2017). Alt1 türü bulunan karrregenan polimeri arasinda enkapsülasyon uygulamalarında en sik kullanilan $x$-karregenandır. Karregenanın ucuz olması ve biyopolimer özellik göstermesi, enkapsülasyon uygulamalarında kaplama materyali olarak tercih edilmesine sebep olmaktadir (Martín vd., 2015; Chakraborty, 2017). Bunun yan1 sira probiyotik hücrelerin mikroenkapsülasyonunda karregenan boncuklarının tercih edilmesinde, karregenanın mikroorganizmanın canlilığna olumlu etki göstermesi ve yoğurt gibi fermente ürünlerdeki organik asitlere karşı düşük duyarlıllğa sahip olması da etkin rol oynamaktadır (Martín vd., 
2015; Sarao ve Arora, 2017). Karregenan kaplama materyali olarak daha çok emülsiyon ve ekstrüzyon yöntemlerinde kullanılmaktadır (Kavitake vd., 2018). Afzaal vd. (2018), probiyotik Lactobacillus acidophilus ATCC4356 suşunu sodyum aljinat ve karragenan polisakkaritleri ile enkapsüle ederek dondurmada ve yapay sindirim sistemi şartlarında canlı kalabilme yeteneğini araştırmışlardır. Araştırmacılar enkapsülasyon uygulamasinin dondurmada ve yapay sindirim sistemi şartlarında probiyotik hücrelerin hayatta kalma düzeyini serbest hücrelere nazaran önemli derecede arttırdığını bildirmişlerdir.

\section{Jellan Gam ve Ksantan Gam}

Mikrobiyal bir polisakkarit olan jellan gamı Pseudomonas elodea'dan elde edilmektedir. Jellan gamı glikoz, glukuronik asit, glikoz ve ramnozun oluşturduğu dört monomerin kendisini tekrarlamas1 ile meydana gelmektedir (Sarao ve Arora, 2017). Negatif yüklü bir ekzopolisakkarit olan jellan gamı doğada biyolojik olarak çözünebilir ve toksik değildir. Jellan gamı metal iyonlarının varlığında sert ve yarı saydam jel üretir. $\mathrm{Bu}$ jel düşük $\mathrm{pH}$ 'da kararlıdır. Bununla birlikte, jellan gam zayıf mekanik dayanıma, fizyolojik koşullarda zayıf kararlılığa ve yüksek jelleşme sicaklığına sahiptir (Zia vd., 2018). Ksantan gam heteropolimer yapıda, glikoz, mannoz ve glukuronik asit monomerlerlerinden oluşan, Xanthomonas campestris bakterisi kullanilarak elde edilen mikrobiyal bir ekzopolisakkarittir (Habibi ve Khosravi-Darani, 2017; Sarao ve Arora, 2017). $\mathrm{Bu}$ iki materyalin mikroenkapsülasyon uygulamalarında kaplama materyali olarak ayrı ayrı ve birlikte kullanımlarının dışında farklı materyallerle kombine kullanımları da bulunmaktadır (Sarao ve Arora, 2017). Probiyotiklerin mikroenkapsülasyonunda kaplama materyali olarak aljinat yerine ksantanjellan gam karışımının kullanılması, kapsüllenmiş hücrenin asidik ortamda dayanımını arttırmaktadır (Kavitake vd., 2018). JiménezPranteda vd. (2009), jellan gam ve ksantam gam karışımı ile Lactobacillus rhamnosus ATCC53103 TM ve Bifidobacterium longum ATCC BAA-999TM probiyotik kültürlerini ekstrüzyon yöntemi kullanarak mikroenkapsüle etmiş ve yapay sindirim sistemi koşullarında serbest ve enkapsüle hücrelerin hayatta kalma düzeyleri incelenmiştir. Safra tuzu uygulaması enkapsüle edilmemiş Lactobacillus sayısında ilk iki saat süresince $3 \mathrm{log}$ kob düşmeye neden olurken, enkapsüle hücrelerde $1 \log$ kob düşüşe neden olmuştur. Bifodobacterium'da ise enkapsüle edilen hücrelerin enkapsüle edilmemiş hücrelere göre sindirim sistemi koşullarına direncinin düşük olduğu bildirilmiştir. Araştırmacilar bifidobakterler ile enkapsülasyonda kullanılan polimerler arasinda negatif etkileşimin olduğunu belirtmişlerdir.

\section{Kitosan}

Kitosan genellikle kabuklu deniz canlılarının kabuk kısımlarından ekstrakte edilen kitinin deasetilasyonu yoluyla elde edilen pozitif yüklü doğrusal bir polisakkarittir (Martín vd., 2015; Wani vd., 2016; Rocha vd., 2017; Huo vd., 2018; Kavitake vd., 2018; Ramos vd., 2018). Kitosan, çözeltilerde stabilite arttırıcı, antimikrobiyal ve antioksidan aktivite güçlendirici özelliklerinin yanı sıra ucuz ve yenilebilir olması nedeni ile ilaç ve g1da endüstrisinde sıklıkla kullanılmaktadır (Rocha vd., 2017). Ayrıca kitosan yapıs1 gereği pH'nın 6'dan düşük olduğu ortamlarda suda çözünebilmektedir. Kitosan, aljinatlar gibi anyon ve polianyonların etkisi ile çapraz bağ kurarak polimerize olmakta ve jel yapma potansiyeli bulunmaktadır (Martín vd., 2015; Sarao ve Arora, 2017). Kitosanın katyonik davranışı ve asidik ortama direnç göstermesi nedeniyle probiyotiklerin gastrointestinal koşullara karşı korunmasında avantaj sağladığını belirten çalışmaların bulunmasının yanı sıra hücrelerin canlılığını korumada düşük düzeyde etkili olduğunu belirten çalışmalar da bulunmaktadır (Rocha vd., 2017; Ramos vd., 2018). De Prisco vd. (2015), kitosan ile kaplamanin Lactobacillus reuteri DSM 17938 suşunun yapay mide ve bağırsak koşullarında hayatta kalma düzeyini geliştirdiğini tespit etmişlerdir. Araştırmacılar enkapsüle edilmiş bakterilerin sayısında önemli bir azalma olmaz iken, enkapsüle edilmemiş hücre sayısında $0.35 \log$ kob'luk bir azalmanın olduğunu bildirmişlerdir. Diğer taraftan, Graff vd. (2008) Saccharomyces boulardi hücrelerini kitosan ile kaplamıslar ancak önemli bir koruma sağlamadığını tespit etmişlerdir. 


\section{Protein Bazlı Kaplama Materyalleri Peynir Altı Suyu Proteinleri}

Peynir üretimi sırasında ortaya çıkan sıvıdan elde edilen peynir altı suyu proteinleri, süt temelli globüler proteinlerin karışımından meydana gelmektedir. $\mathrm{Bu}$ proteinler çok çeşitli aktif moleküllerle etkileşime girme yeteneğine sahiptir. Bu durum konakçıda hedeflenen salınımlarından önce aktif moleküllerin korunmas1 ve ters bağlanması için çeşitli imkanlar sunmaktadır (Martín vd., 2015). Süt proteinleri, yüksek besin değeri, çözelti içerisinde düşük viskozite, kolay çözünme, iyi emülsiyon gibi fonksiyonel özellikler göstermeleri nedeni ile enkapsülasyon uygulamalarnda polimerik hidrojellere alternatif olarak kullanılmaktadır (Martín vd., 2015; Kumar vd., 2018). Ayrıca jelleşme özelliklerinin çok iyi olmas1 bakterilerin enkapsülasyon uygulamalarında kullanımlarına olanak sağlamaktadır. Bu özellikleri sayesinde peynir altı suyu proteinlerinin sulu çözeltilerinden elde edilen mikrokapsüller yüksek yoğunlukta jel yap1 olușturmaktadır. Ağa benzeyen bu jel yap1 probiyotik mikroorganizmaları daha iyi koruyarak gidalarda daha etkin kullanilmalarını sağlamaktadır (Abd El-Salam ve El-Shibiny, 2015). Peynir alt1 suyu proteinlerinin bu özellikleri sonucu, kaplama materyali olarak kullanıldıkları mikroenkapsüle probiyotik kültürlerin, gastrointestinal geçiş sırasında canlı formda kalma potansiyelleri oldukça yüksektir (Ramani ve Ramani, 2018). Doherty vd. (2012), jelleşmiş peynir altı suyu boncuklarına tutuklanmış ve tutuklanmamış Lactobacillus rbamnosus GG hücrelerinin ex vivo domuz sindirim sisteminde (mide-alt karın, bağırsak-ileum ve çekum) hayatta kalma düzeylerini araştırmışlardır. Tutuklanmamış serbest hücreler midede $(\mathrm{pH} 3.4) 30$ dakika inkübasyon sonunda hayatta kalamamış iken, tutuklanmış hücreler 180 dakika inkübasyon sonunda $\mathrm{pH} 3.4,2.4$ ve 2.0 'da sirasiyla $5.7 \pm 0.1$, $5.1 \pm 0.2$ ve $2.2 \pm 0.2 \mathrm{log} \mathrm{kob} / \mathrm{mL}$ düzeyinde canlı kalmışlardır. Elde edilen sonuçlar, protein mikroboncuklarına tutuklanmış hücrelerin asit direncinin arttığını $(8.9 \pm 0.1 \quad \log \mathrm{kob} / \mathrm{mL})$, adsorpsiyon kapasitesinin yüksek olduğunu ve intestinal inkübasyonda 30 dakika içinde probiyotik hücrelerin kontrollü salınımının gerçekleştiğini göstermiștir. Araştırmacılar peynir altı suyu mikroboncuklarının biyoaktif bileşenlerin mikroenkapsülasyonunda bağlayıcı materyal olarak kullanılabileceğini belirtmişlerdir.

\section{Jelatin}

Jelatin, kolajenin kısmi hidroliziyle elde edilen biyobozunur bir proteindir (Shaddel vd., 2018). Jelatin saf halde, yar1 saydam, kırlgan, renksiz veya hafif sarı, tatsız ve kokusuz özelliktedir (Kavitake vd., 2018). Jelatin yüksek emülsifiye etme kapasitesi, sudaki çözünürlüğü, yüksek stabilize edici aktivitesi ve birincil amino grubu boyunca yüksek çapraz bağlama aktivitesi gibi özelliklere sahip olması nedeni ile mikroenkapsülasyon uygulamalarında kaplama materyali olarak kullanilmaktadır (Shaddel vd., 2018). Jelatin amfoterik yapisı nedeniyle jellan gamı gibi anyonik polisakkaritlerle sinerjik etki gösterebilmektedir. $\mathrm{Bu}$ iki hidrokolloidin birbirlerini itme eğiliminde olması ve negatif yük taşımaları nedeniyle sadece 6 'dan daha yüksek $\mathrm{pH}$ değerlerinde karıșabilmektedirler. Bununla birlikte, karıșımın pH'sı jelatinin izoelektrik noktasının altında ayarlandığı zaman jelatin üzerindeki net yük pozitif hale geçmekte ve negatif yüklü jellan gamı ile etkileşime girebilmektedir. Söz konusu karışım bazı gıdaların ve bakterilerin mikroenkapkülasyonunda destek materyali olarak kullanılmaktadır (Martín vd., 2015; Sarao ve Arora, 2017). Arslan vd. (2015), püskürtmeli kurutma yöntemi ile Saccharomyces boulardi enkapsülasyonunda jelatin, peynir altı suyu protein konsantresi, modifiye nişasta, maltodekstrin, bezelye proteini ve gam Arabik'i kaplama materyali olarak kullanmışlardır. Araştırmacılar yapay mide solüsyonunda farklı $\mathrm{pH}$ değerleri ve sürelerde $S$. boulardi hücrelerinin hayatta kalmasında en etkili kaplama materyalinin gam Arabik olduğunu bunu jelatin ve bezelye proteininin izlediğini tespit etmişlerdir.

\section{Nohut Proteinleri}

Baklagillerde yüksek miktarda değerli protein bulunmaktadır. Baklagil proteinleri yüksek besleyici özelliklerinin yanı sıra oksidasyon önleyici etkiye de sahiptir. Aynı zamanda nutrasötik madde ve fonksiyonel gidalarda da başarıyla kullanılmaktadır. Nohut proteinlerinin biyoaktif bileşiklerin kapsüllenmesi için 
kullanılmalarında ana itici güç, GRAS statüsünde olmalar1 ve baklagil türevli proteinlerin emülsifiye edici özelliklere sahip olmalarıdır (Sharif vd., 2018). Son ylllarda nohut proteinleri, fonksiyonel özellikleri, besinsel değerinin yüksek olması ve doğal olması nedeniyle mikroenkapsülasyon proseslerinde kaplama materyali olarak siklikla tercih edilmektedir. $\mathrm{Bu}$ proteinlerin alerjenik özelliklerinin az olması mikroenkapsülasyon uygulamasında kullanılmasının bir başka temel sebebini oluşturmaktadır. Nohutta bulunan başlica proteinler tuzlu ortamda çözünebilen globülin tipi depolama proteinleri olan legumin ve visilindir (Wang vd., 2014; Martín vd., 2015). Wang vd. (2014), emülsiyon teknolojisi kullanarak nohut proteini-aljinat mikrokapsülleri geliştirmişlerdir. Araştırmacılar mikrokapsüllerin Bifidobacterium adolescentis'i yapay mide suyuna karş1 koruduğunu ve nohut proteini-aljinat kapsüllerinin gıda uygulamaları için uygun bir probiyotik taşıyıc1 görevi görebileceğini bildirmişlerdir.

\section{Selüloz Asetat Fitalat (CAP)}

$\mathrm{Bu}$ polimer yapıdaki bileşen, güvenilirliğinin yüksek seviyede olması sebebi ile bağırsaklarda ilaç salınımını kontrol etmek amacıyla kullanılmaktadır. Kullanılmasının temelindeki en büyük avantaj, pH'nın 5'den küçük olduğu kuvvetli asit ortamlarda çözünmemesine rağmen 6 ve 6'dan daha yüksek pH'larda çözünme potansiyeline sahip olmasıdır. Bu bağlamda, bakterilerin mikrokapsülasyonunda CAP kullanımı kolona çok sayıda canlı bakteriyel hücre taşınmasını sağlamaktadır (Sarao ve Arora, 2017; Kavitake vd., 2018). Fávaro-Trindade ve Grosso (2002), kaplama materyali olarak CAP kullanarak probiyotik Lactobacillus acidophillus (La-05) ve Bifidobacterium lactis (Bb-12) suşlarını püskürtmeli kurutma yöntemi ile enkapsüle etmişler ve serbest ve mikroenkapsüle edilmiş probiyotik kültürlerin farklı $\mathrm{pH}$ ve safra tuzu konsantrasyonlarına dayanımlarını araştırmışlardır. Araştırmacılar mikroenkapsülasyon işleminin düşük $\mathrm{pH}$ 'da kültürlerin korunmasinda etkili olduğunu bildirmişlerdir. Her iki bakteri içinde serbest hücrelerin asidik koşullarda 1 saat sonra elemine olduklarını tespit etmişlerdir. Ayrıca, hem serbest hem de mikroenkapsüle edilmiş L. acidophillus ve
B. lactis hücrelerinin 12 saat sonunda safra solüsyonuna dirençli olduğunu bildirmişlerdir.

\section{Mikroenkapsülasyon Yöntemleri}

Gıda endüstrisi ürünlerin lezzet, renk ve doku gibi özelliklerini geliştirmenin yanı sıra raf ömrü gibi kalite kriterlerini de iyileştirmek için birçok fonksiyonel bileşen kullanmaktadır. Özellikle son yıllarda tüketicilerin artan sağlıklı ürün talepleri probiyotik kültür ve doğal antimikrobiyal maddeleri daha da ilgi çekici hale getirmiştir. Bu bileşenlerin çoğunun düşük stabiliteye sahip olması çevresel faktörler tarafindan kolaylıkla etkilenmelerine neden olmakta bu da sağlıklı gida üretiminde kullanılmaları açısından dezavantaj oluşturmaktadır. Bu sebeple gida endüstrisi için yüksek stabiliteye sahip bileşenlerin hazırlanması önem kazanmıştır. Son yıllarda fonksiyonel gıdaların popülerliğinin artması ve yüksek verimli mikrokapsüllerin üretilmesi, mikroenkapsülasyon teknolojisinin kullanıldığı fonksiyonel bileşenlerin gıda sanayisinde kullanımını arttırmıştır (Peanparkdee vd., 2016). Ekstrüzyon tekniği, sprey kurutma, sprey dondurma veya sprey soğutma, ekstrüzyon kaplama, akışkan yatak kaplama, lipozomal tuzaklama, liyofilizasyon, koaservasyon, çift kapsülleme gibi yöntemler mikroenkapsülasyon uygulamalarında kullanılmaktadır (Celli vd., 2015; Đordevic' vd., 2015; Mohan vd., 2015; Peanparkdee vd., 2016; Kavitake vd., 2018; Quintero vd., 2018; Ramani ve Ramani, 2018). Bu derlemede probiyotik kültürlerin mikroenkapsülasyonunda kullanılan farklı yöntemler ele alınmıstır.

\section{Ekstrüzyon}

Ekstrüzyon yöntemi, yüksek hücre canlılığı, düşük maliyet ve basit formülasyon gibi özellikleri sayesinde diğer mikroenkapsülasyon yöntemlerine göre mikroorganizmaların enkapsülasyonunda daha yaygin olarak kullanılmaktadır (Kavitake vd., 2018). Ekstrüzyon yöntemi aktif materyali içeren hidrokolloid bir çözeltinin, şırınga iğnesi ile boncuklar halinde sertleştirme çözeltisine damlatılması sonucu katılaşması prensibine dayanmaktadır (Martín vd., 2015; Uran vd., 2017). Ekstrüzyon yöntemi genellikle gida sanayinde düşük sıcaklıklarda uygulama gerektiren uçucu ve stabilitesi zayıf olan aroma maddelerinin mikroenkapsülasyonu için 
tercih edilmektedir (Altun ve Özcan, 2013). Bu yöntemde destek materyali olarak aljinat, peynir altı suyu proteinleri, pektin, süt ve insan kollejeni gibi bileşenler kullanılmaktadır. Yöntemin önemli avantajları: uygulamada organik çözücülere ihtiyaç duyulmamas1, boncuk boyutunun ayarlanabilir olması ve oksijene karşı bariyer oluşturarak oksidasyon potansiyeli yüksek lezzet bileşenlerinin raf ömrünü uzatmasıdır (Martín vd., 2015). Ayrıca yöntemin uygulama basitliği, düşük maliyet ve uzun süreli hücre canlıllğında stabilite sağlaması gibi önemli avantajları bulunmaktadır (Uran vd., 2017). Ekstrüzyon yönteminin dezavantajları ise mikrokapsül oluşum hızının düşük olması ve büyük çaplı damlacıklar $(2 \mathrm{~mm})$ elde edilmesi sonucu endüstriyel uygulamalarda yetersiz kalmasıdır (Đordevic' vd., 2015).

\section{Emülsiyon}

Emülsiyon yönteminde kesikli faz (hücre polimer süspansiyonu) büyük hacimdeki yağ (sürekli faz) içerisine eklenir ve yağ içerisinde su emülsiyonu elde etmek için karışım homojenize edilir. Yağ içerisinde su emülsiyonu oluştuğunda suda çözünür polimerler, yağ fazında çözünmeyen küçük jel yapıları oluşturmaktadır (Azagheswari vd., 2015; Martín vd., 2015; Coghetto vd., 2016; Giro-Paloma vd., 2016). Hazırlanan emülsiyonun iç fazındaki partiküllerin boyutunun küçüklüğü elde edilecek mikrokapsüllerin boyutunu değiştirmektedir. Oluşan damlacıklar filtrasyon yardımı ile sıvı çözeltiden uzaklaştırılmaktadır. Elde edilen damlacık boyutu çalkalama hızına bağlı olarak $25 \mu \mathrm{m}$ ile $2 \mathrm{~mm}$ arasinda değişmektedir (Heidebach vd., 2012). Gida uygulamalarında sürekli faz olarak daha çok bitkisel yağlar (ayçiçeği, kanola, mısır, soya vb.) tercih edilmektedir (Martín vd., 2015; Coghetto vd., 2016). Daha iyi bir emülsiyon elde etmek için yüzey gerilimini azaltarak daha küçük parçaların oluşmasına yardımcı olan emülgatörlerde karışıma eklenmektedir. Karregenan, sodyum karbosimetil selüloz, CAP, aljinat ve kombinasyonları, kitosan, jelatin, nohut proteini bu yöntemde kullanılan destek materyalleri arasinda bulunmaktadır (Martín vd., 2015).

\section{Akışkan Yatak}

Akışkan yatak kaplama yöntemi gözenekli katılara absorbe edilen sıviları içeren katı çekirdek malzemelerin kapsüllenmesi için kullanılmaktadır (Azagheswari vd., 2015). 1950'li y1llarda ilaç tabletlerin kaplanması için geliştirilen akışkan yatak kaplama yöntemi günümüzde gida endüstrisinde kat1 maddelerin ve fonksiyonel materyallerin de enkapsülasyonu için kullanılan bir yöntem halini almışır (Desai ve Park, 2005). Bu sistem hücre süspansiyonunun inert taşıyıcılar üzerine püskürtülerek kurutulması temeline dayanmaktadır (Martín vd., 2015). Kaplanacak materyaller, kaplama odasina isitilan veya soğutulan hava yardımı ile taşınır. Partiküller odada oluşan düşük hava akımı ve geri dönüş istekleri nedeniyle çeperlere doğru hareket eder. Uygun çözücüde çözülen kaplama materyali atomize edilerek odaya bir sis bulutu şeklinde verilir ve havada asılı kalan partiküllerin kaplanması sağlanır. Hava odasında bulunan mikro filtreler yardımı ile partiküller tekrar hava kaplama odasina döner ve daha iyi bir kaplama sağlanır. Tüm bu işlemler sonucunda odadan alınan 11ık sıcaklığa sahip ürün tekrar kurutularak ambalajlanır (Desai ve Park, 2005). Toplam sıcaklık kontrolü ve düşük maliyet bu sistemin avantajları arasında yer almaktadır. Ancak yetişmiş eleman ihtiyacı ve nispeten uzun süreli bir işlem olması yöntemin dezavantajları arasında sayılabilir (Martín vd., 2015).

\section{Rennet ile Jelleşmiş Protein Enkapsülasyonu} Bu yöntem gıda kaynaklı bir enzim olan rennet ve sulu süt protein solüsyonu kullanilarak mikrokapsüller oluşturulması temeline dayanmaktadır. Rennet kazein misellerinin agregasyonunu sağlayan k-kazein misellerini parçalayabilen proteolitik bir enzim kompleksidir. Kovalent olmayan çapraz bağlar $18^{\circ} \mathrm{C}^{\prime}$ nin üstündeki sıcaklıklarda nihai jel oluşturmak üzere topaklaşan misellerin zincirleri arasında aşamalı olarak meydana gelmektedir. Bu özelliği nedeni ile bu teknik sonucu meydana gelen mikrokapsüller sayesinde probiyotikler enkapsülasyon işlemi boyunca canlilıklarını kaybetmezler. Bu durum protein tamponlama kapasitesinin neden olduğu yüksek pH'ya sahip matriksin koruyucu etkisi ile açıklanmaktadır. Ayrıca oluşturulan kapsül boyutlarının kontrolü ile son ürünün duyusal özelliklerinin iyileştirilebilmesi bu yöntemin avantajları arasındadır. Tüm bu nedenlerden 
dolay1, bu yöntem gidalarda probiyotiklerin daha etkili bir şekilde kullanılması için uygun bir yaklaşım olarak değerlendirilmektedir (Martín vd., 2015).

\section{Dondurarak Kurutma}

Dondurarak kurutma probiyotik preparatlarin hazırlanması için kullanılan eski bir yöntem olsa da bu yöntemin enkapsülasyon uygulamalarında kullanımı nispeten yeni bir yöntemdir (Martín vd., 2015; Coghetto vd., 2016). Dondurarak kurutma prosesi üç aşamadan oluşmaktadır. Bu aşamalar süblimasyona dayanan dondurma ve birincil ve ikincil kurutma isslemleridir. Temel olarak yöntemin çalışma prensibi kurutulacak olan materyalin önce dondurulması sonrasında yüksek vakum altında süblimasyon ile kurutulması esasına dayanmaktadır (Martín vd., 2015). Dondurarak kurutma işlemi sırasında oluşan kristaller ve yüksek ozmotik basınç hücre canlılı̆̆ını etkilediğinden bu işlem öncesinde ortama kriyoprotektan özellik gösteren süttozu, peynir altı suyu proteini, glikoz ve maltodekstrin gibi koruyucular eklenmektedir (Martín vd., 2015; Coghetto vd., 2016). Dondurarak kurutma yönteminin, aroma kayıplarını azaltması, elde edilen ürünlerin rekonstitüsyon özelliklerinin çok iyi olması, gıda içerisinde çözünen maddelerin hareketi sonucu oluşan kayıpları minimize etmesi gibi sağlamış olduğu avantajların yanı sıra maliyetinin yüksek olması ve işlem süresinin uzunluğu gibi dezavantajları da bulunmaktadır. $\mathrm{Bu}$ yöntem püskürtmeli kurutmaya göre daha 1lımlı bir yöntem olsa da mikroenkapsülasyon uygulamalarında ekonomik nedenler ile kullanımı sinırlıdır (Koç vd., 2010).

\section{Püskürtmeli Kurutma}

Püskürtmeli kurutma yöntemi genellikle bir kurutma yöntemi olarak düşünülse de, aktif materyalin koruyucu polimer bir matriks içerisinde hapsedilmesine olanak sağlaması nedeniyle, son zamanlarda mikroenkapsülasyon tekniği olarak da kullanılmaktadır (Öztürk ve Çakır, 2015). Gıda endüstirisinde bu yöntem, üründe su aktivitesinin azaltılarak mikrobiyal stabilitenin sağlanması, bozulma faktörlerini engelleyerek son kullanma tarihini arttırması ve depolama ve taşıma maliyetlerinin azaltılması amacıyla kullanılmaktadır (Altun ve Özcan, 2013).
Bu yöntem ile elde edilen mikrokapsüle edilmiş ürünlerin maliyetinin düşük olması ve sağlamış olduğu avantajlar nedeni ile püskürtmeli kurutma gida sanayinde en yaygin kullanılan mikroenkapsülasyon yöntemlerinin başında gelmektedir. Püskürtmeli kurutma prosesi; çekirdek malzemenin sisteme ve ürüne uygun bir kaplama materyali içeren çözelti içerisinde oluşturduğu dispersiyon ve emülsiyon karışımının homojen hale getirilmesi ve bu karışımın atomize edilerek kurutma odasina gönderilmesi esasina dayanmaktadır (Martín vd., 2015). Püskürtmeli kurutma yönteminin sağlamış olduğu en büyük avantajlardan biri maliyetinin düşük olmasının yanında sürekli üretime uygun olmasıdır. Fakat yüksek sıcaklığa duyarlı probiyotik bakteri kültürlerinin kapsüllenmesinde kullanıldığında canlilık oranlarında düşüşe sebep olmaktadır (Schuck vd., 2016). Bu olumsuz etkinin giderilebilmesi için sistem giriş ve çıkış sicakliklarının ayarlanması ve kontrol edilmesi ile istenilen partikül boyutu dağılımına sahip enkapsüle edilmiş canlı kültür elde edilebilmektedir. $\mathrm{Bu}$ nedenle püskürtmeli kurutma yönteminde modifikasyonlar yapılmakta veya farklı yöntemler ile kombine edildiği sistemler geliştirilmektedir. $\mathrm{Bu}$ yöntemlerin başında iki aşamalı kurutma, püskürtmeli dondurarak kurutma, püskürtmeli dondurma, ultrasonik vakumlu püskürtmeli kurutma gibi yöntemler gelmektedir (Martín vd., 2015).

\section{Hibridizasyon Sistemi}

Hibridizasyon sistemi kisaca kuru kapsülleme yöntemi olarak da adlandırlmaktadır. Sistem altı bıçaklı yüksek hızda dönen bir rotor, sabit bir bobin ve toz devridaim devresinden oluşmaktadır. Toz karışım yüksek hızda dönen bıçaklar tarafindan oluşturulan darbeye maruz birakılarak, karışım içerisindeki yardımcı partiküllerin probiyotiklerin yüzeyinde bir film oluşturması sağlanmaktadır. Hibridizasyon sistemi ile yüksek miktarlarda mikrokapsül elde edilmektedir. Ayrıca sistem içerisinde bir soğutma ünitesi kullanılarak sicaklık $30{ }^{\circ} \mathrm{C}$ 'nin altında tutulur. Bu sayede 1s1 kaynaklı bakteriyel hasar en aza indirilebilmektedir. Bu yöntem ile yüksek verim elde edilirken aynı zamanda bakterilerin yüksek sıcaklıktan korunması da sağlanmaktadır (Martín vd., 2015). 


\section{Çarpışan Aerosol Teknolojisi}

Son yllarda mikroenkapsülasyon uygulama alanının artması ama buna karşın mevcut enkapsülasyon yöntemlerinin süreklilik konusundaki dezavantajları çarpışan aerosol teknolojisinin geliştirilmesine neden olmuştur (Sohail vd., 2012). Çarpişan aerosol teknolojisinin kullanıldığ1 sistemlerde aljinat solüsyonu içerisinde bulunan mikrobiyal süspansiyon ile kalsiyum klorid olmak üzere iki farklı aerosol kullanılmaktadır. Aljinat karışımı bir silindirin üst tarafindan enjekte edilirken alt taraftan da kalsiyum klorid solüsyonu enjekte edilmektedir. Elde edilen mikrokapsüllerin ortalama çap 40 $\mu$ m'den küçüktür. Çarpışan aerosol teknolojisinde 1S1 yada çözücü kullanılmadığından, 1sıya ve çözücülere duyarlı maddelerin enkapsülasyonunda kullanılabilmektedir. Ayrıca çarpişan aerosol teknolojisi yüksek üretim kapasitesine sahiptir. Üretilen mikroboncuklar sprey kurutma ve dondurarak kurutma yöntemleri ile de kurutulabilmektedir (Martín vd., 2015).

\section{Elektrodöndürme Yöntemi (Elektrospinning)}

Elektrodöndürme yöntemi yüksek elektrik alan temeline dayanan, kolay uygulanabilir, kullanışlı ve çok yönlü bir teknolojidir (Chen vd., 2012). Bu yöntemde, elektrot gibi davranan bir kalıbın ucundan gelen çözelti veya eriyiğe yüksek elektrik alan uygulanir. $\mathrm{Bu}$ işlem, damlacık deformasyonuna ve sonuç olarak yüklü bir jet ucundan sayaç elektroduna doğru çözelti/eriyiğin firlatılması ile sürekli lif oluşumuna yol açar (Martín vd., 2015). Farkl1 morfolojik yapılarda ürün elde edilmesine olanak taniyan elektrodöndürme tekniği ile elde edilen bu yapıların morfolojileri uygulanan işlem parametrelerinin farklılı̆̆na göre değişmektedir (Chen vd., 2012). Elektrodöndürme yöntemi ile protein veya karbonhidrat bazl matriksler kullanılarak mikrokapsüller üretilebilmektedir (Martín vd., 2015).

\section{SONUÇ}

Probiyotik hücrelerin olumsuz çevresel koşullarda canlılıklarını kolay kaybetmesi gıda üretiminde kullanılmaları açısından dezavantaj oluşturmaktadır. Bu sebeple gıda endüstrisinde mikroenkapsüle edilmiş probiyotik kültürlerin kullanımı gün geçtikçe artmaktadır. Mikroenkapsülasyon yöntemleri ile kaplanan probiyotik hücrelerin çevre koşullarına karşı korunumu ve istenilen zamanda salınımının sağlanması ile konak canlıda maksimum biyoyarar elde edilmesi hedeflenmektedir. Probiyotik mikroorganizmların etkinliği ve hayatta kalabilmesi suşa ve kullanılan kaplama materyaline göre değişmektedir. Mikroenkapsülasyon yöntemi kullanımında öne çıkan en önemli konu, kullanılacak ürüne, ortama ve şartlara uygun mikroenkapsülasyon yönteminin belirlenmesi ve kaplama materyalinin seçimidir. Mevcut yöntemler ve kaplama materyallerinin taşıdıkları dezavantajlar nedeni ile mikroenkapsüle ürünler henüz raflarda istenilen düzeyde yerini alamamaktadır. $\mathrm{Bu}$ bağlamda yeni mikroenkapsülasyon yöntemlerinin geliştirilmesi, bu yöntemlere uygun kaplama materyali ve karışımlarının araştırılması mikroenkapsülasyon uygulamalarının verimini arttıracaktır. Bununla birlikte endüstriyel uygulamalar için sürekli üretime olanak tanıyan ekipmanların geliştirilmesine de ihtiyaç duyulmaktadır.

\section{KAYNAKLAR}

Abd El-Salam, M.H., El-Shibiny, S., (2015). Preparation and properties of milk proteins-based encapsulated probiotics: a review. Dairy $S_{c i}$ Technol, 95: 393-412.

Afzaal, M., Saeed, F., Arshad, M.U., Nadeem, M.T., Saeed, M., Tufail, T., (2018). The effect of encapsulation on the stability of probiotic bacteria in ice cream and simulated gastrointestinal conditions. Probiotics Antimicro Prot, 1-7.

Albadran, H.A., Chatzifragkou, A., Khutoryanskiy, V.V., Charalampopoulos D., (2018). Development of surfactant-coated alginate capsules containing Lactobacillus plantarum. Food Hydrocolloids, 82: 490-499

Altun, B., Özcan, T., (2013). Süt ürünlerinde probiyotik bakterilerin mikroenkapsülasyonu II: kaplama materyalleri ve süt ürünlerinde uygulamalar. Uludă̆ Üniv Ziraat Fak Derg, 27(2): 105-114. 
Arepally, D., Goswami, T.K., (2019). Effect of inlet air temperature and gum Arabic concentration on encapsulation of probiotics by spray drying. LWT- Food Sci Technol, 99: 583-593.

Arslan-Tontul, S., Erbas, M., (2017). Single and double layered microencapsulation of probiotics by spray drying and spray chilling. LWT - Food Sci Technol, 81: 160-169.

Atak, Z., Koç, M., Kaymak-Ertekin, F., (2017). Gıda endüstrisinde aroma mikroenkapsülasyonu. Akad Grda, 15: 416-425.

Azagheswari, Kuriokase, B., Padma, S., Padma Priya, S., (2015). A review on microcapsules. Glob J Pharmacol. 9: 28-39.

Başyigit, B., Hayoğlu, I., Atasoy, F., (2017). Kekik esansiyel yağ1 ve mikroenkapsülasyon uygulamalan. Batman Üniv Yaşam Bilim Derg 7: 6370.

Çakır, İ., (2006). Mikroenkapsülasyon tekniğinin probiyotik gida üretiminde kullanımı. Türkiye 9. Gıda Kongresi, 24-26 Mayıs 2006, Bolu, Türkiye, 693-696.

Celli, G.B., Ghanem, A., Brooks, M.S.L., (2015). Bioactive encapsulated powders for functional foods-a review of methods and current limitations. Food Bioprocess Technol. 8: 1825-1837.

Chakraborty, S., (2017). Carrageenan for encapsulation and immobilization of flavor, fragrance, probiotics, and enzymes: A review. $J$ Carbohydr Chem, 36: 1-19.

Chen, C., Liu, S., Liu, W., Zhao, Y., Lu, Y., (2012). Synthesis of novel solidliquid phase change materials and electrospinning of ultrafine phase change fibers. Sol Energy Mater Sol Cells, 96: 202209.

Chen, J., Wang, Q., Liu, C.M., Gong, J., (2017). Issues deserve attention in encapsulating probiotics: Critical review of existing literature. Crit Rev Food Sci Nutr, 57: 1228-1238.

Coelho-Rocha, N.D, de Castro, C.P., de Jesus, L.C.L., Leclercq, S.Y., de Cicco Sandes, S.H., Nunes, A.C., Azevedo, V., Drumond, M.M., Mancha-Agresti, P., (2018). Microencapsulation of lactic acid bacteria improves the gastrointestinal delivery and in situ

expression of recombinant fluorescent protein. Frontiers Microbiol, 9: 2398.

Coghetto, C.C., Brinques, G.B., Ayub, M.A.Z., (2016). Probiotics production and alternative encapsulation methodologies to improve their viabilities under adverse environmental conditions. Int J Food Sci Nutr, 67: 929-943.

De Prisco, A., Maresca, D., Ongeng, D., Mauriello, G., (2015). Microencapsulation by vibrating technology of the probiotic strain Lactobacillus reuteri DSM 17938 to enhance its survival in foods and in gastrointestinal environment. LWT-Food Sci Technol, 61: 452-462.

De Prisco, A., Mauriello, G., (2016). Probiotication of foods: A focus on microencapsulation tool. Trends Food Sci Technol, 48: 27-39.

De Prisco, A., van Valenberg, H.J.F., Fogliano, V., Mauriello, G., (2017). Microencapsulated starter culture during yoghurt manufacturing, effect on technological features. Food Bioprocess Technol, 10: 1767-1777.

Desai, K.G.H., ve Park, H.J., (2005). Recent developments in microencapsulation of food ingredients. Drying Technol, 23(7): 1361-1394

Dianawati, D., Mishra, V., Shah, N.P., (2016). Survival of microencapsulated probiotic bacteria after processing and during storage: A review. Crit Rev Food Sci Nutr, 56: 1685-1716.

Đordevic', V., Balanc ${ }^{\vee}$, B., Belscak-Cvitanovic', A., Levic', S., Trifkovic', K., Kalusevic', A., Kostic', I., Komes, D., Bugarski, B., Nedovic, V., (2015). Trends in encapsulation technologies for delivery of food bioactive compounds. Food Eng Rev, 7: 452-490.

Doherty, S.B., Auty, M.A., Stanton, C., Ross, R.P., Fitzgerald, G.F., Brodkorb, A., (2012). Survival of entrapped Lactobacillus rbamnosus GG in whey protein micro-beads during simulated ex vivo gastro-intestinal transit. Int Dairy J, 22: 31-43

Espitia, P.J.P., Batista, R.A., Azeredo, H.M.C., Otoni, C.G., (2016). Probiotics and their potential 
applications in active edible films and coatings. Food Res Int, 90: 42-52.

Fávaro-Trindade, C.S., Grosso, C.R., (2002). Microencapsulation of $L$. acidophilus (La-05) and B. lactis (Bb-12) and evaluation of their survival at the $\mathrm{pH}$ values of the stomach and in bile. $J$ Microencapsul, 19(4): 485-494.

Gbassi, G.K., Vandamme, T., Ennahar, S., Marchioni, E., (2010). Microencapsulation of Lactobacillus plantarum spp. in an alginate matrix coated with whey proteins. Int J Food Microbiol, 129: 103-105.

Giro-Paloma, J., Martínez, M., Cabeza, L.F., Fernández, A.I., (2016). Types, methods, techniques, and applications for microencapsulated phase change materials (MPCM): A review. Renew Sustain Energy Rev, 53: 1059-1075.

Graff, S., Hussain, S., Chaumeil, J. C., \& Charrueau, C. (2007). Increased intestinal delivery of viable Saccharomyces boulardii by encapsulation in microspheres. Pharm Res, 25: 1290-1296.

Gökbulut, İ., Öztürk, F.S., 2018. G1da mikroenkapsülasyonunda aljinat kullanımı. Batman Üniv Yaşam Bilim Derg, 8(1/2), 16-28.

Habibi, H., Khosravi-Darani, K., (2017). Effective variables on production and structure of xanthan gum and its food applications: A review. Biocatal Agric Biotechnol, 10: 130-140.

Heidebach, T., Först, P., Kulozik, U., (2012). Microencapsulation of probiotic cells for food applications. Crit Rev Food Sci Nutr, 52: 291-311.

Huo, X., Li, W., Wang, Y., Han, N., Wang, J., Wang, N., Zhang, X., (2018). Chitosan composite microencapsulated comb-like polymeric phase change material via coacervation microencapsulation. Carbohydr Polym, 200: 602610.

Jiménez-Pranteda, M.L., Poncelet D., RamosCormenzana, A., Monteoliva-Sanchez, M., (2009). Viability of probiotics exopolymers beads exposed to specific in vitro conditions. XVII'th International Conference on Bioencapsulation, 24-26 September, Groningen, Netherlands, Poster P85.
Kailasapathy K., (2006). Survival of free and encapsulated probiotic bacteria and their effect on the sensory properties of yoghurt. Lebensm Wiss Technol, 39: 1221-1227.

Kavitake, D., Kandasamy, S., Devi, P.B., Shetty, P.H., (2018). Recent developments on encapsulation of lactic acid bacteria as potential starter culture in fermented foods - A review. Food Biosci, 21: 34-44.

Koç, M., Sakin, M., Ertekin, F.K., (2010). Mikroenkapsülasyon ve gida teknolojisinde kullanımı. Pamukekale Üniv Müh Bilim Derg, 16: 7786.

Kumar, B.V., Venkata, S., Vijayendra, N., (2015). Trends in dairy and non-dairy probiotic products - a review. J Food Sci Technol, 52(10): 6112-6124.

Kumar, R., Chauhan, S.K., Shinde, G., Subramanian, V., Nadanasabapathi, S., (2018). Whey proteins: A potential ingredient for food industry - a review. Asian J Dairy Food Res, 37: 283-290.

Li, H., Thuy Ho, V.T., Turner, M.S., Dhital, S., (2016). Encapsulation of Lactobacillus plantarum in porous maize starch. LWT - Food Sci Technol, 74: 542-549.

Marcial-Coba, M.S., Knøchel, S., Nielsen, D.S., (2019). Low-moisture food matrices as probiotic carriers. FEMS Microbiol Lett, 366: 1-11.

Martín, M.J., Lara-Villoslada, F., Ruiz, M.A., Morales, M.E., (2015). Microencapsulation of bacteria: A review of different technologies and their impact on the probiotic effects. Innov Food S $c i$ Emerg Technol, 27: 15-25.

Mohan, A., Rajendran, S.R.C.K., He, Q.S., Bazinet, L., Udenigwe, C.C., (2015). Encapsulation of food protein hydrolysates and peptides: A review. RSC Adv, 5: 79270-79278.

O'Riordan, K., Andrews, D., Buckle, K., Conway, P., (2001). Evaluation of microencapsulation of a Bifidobacterium strain with starch as an approach to prolonging viability during storage. $J$ Appl Microbiol, 91: 1059-1066. 
Öztürk, S., Çakıı, İ., (2015). Mikroorganizma kültürlerinin korunmasinda kullanılan kurutma yöntemleri. Akad Gıda, 13 (1), 94-100.

Pandey, K.R., Vakil, B.V., (2017). Encapsulation of probiotic Bacillus coagulans for enhanced shelf life. J Appl Biol Biotechnol, 5: 57-65.

Paulo, F., Santos, L., (2017). Design of experiments for microencapsulation applications: A review. Mater Sci Eng C, 77: 1327-1340.

Peanparkdee, M., Iwamoto, S., Yamauchi, R., (2016). Microencapsulation: A review of applications in the food and pharmaceutical industries. Rev Agric Sci, 4: 56-65.

Picot, A., Lacroix, C., (2004). Encapsulation of bifidobacteria in whey protein-based microcapsules and survival in simulated gastrointestinal conditions and in yoghurt. Int Dairy J, 14: 505-515.

Pradeep Prasanna, P.H., Charalampopoulos, D., (2018). Encapsulation in an alginate-goats' milkinulin matrix improves survival of probiotic Bifidobacterium in simulated gastrointestinal conditions and goats' milk yoghurt. Int J Dairy Technol, 72(1): 132-141.

Quintero, J., Rojas, J., Ciro, G., (2018). Vegetable proteins as potential encapsulation agents: A review. Food Research, 2(3): 208-220.

Ramani, R., Ramani, V., (2018). Probiotic microencapsulation techniques and coating materials. Int J Probiotics Prebiotics, 13: 161-168.

Ramos, P.E., Cerqueira, M.A., Teixeira, J.A., Vicente, A.A., (2018). Physiological protection of probiotic microcapsules by coatings. Crit Rev Food Sci Nutr, 58:1864-1877.

Rocha, M.A.M., Coimbra, M.A., Nunes, C., (2017). Applications of chitosan and their derivatives in beverages: A critical review. Curr Opin Food Sci, 15: 61-69.

Roshanzamir, M., Jafari, M., Molaee, E., Ghasemkhani, I., (2017). The survival of probiotic bacteria and sensory properties of yogurt affected by microencapsulation with resistant starch 3. J Food Safe \& Hyg, 3(3/4): 5964.
Sagis, L.M. (2015). Microencapsulation and microspheres for food applications. Academic Press, p.235-248, ISBN 9780128003503

Sarao, L.K., Arora, M., (2017). Probiotics, prebiotics, and microencapsulation: A review. Crit Rev Food Sci Nutr, 57: 344-371.

Schuck, P., Jeantet, R., Bhandari, B., Chen, X.D., Perrone, Í.T., de Carvalho, A.F., Fenelon, M., Kelly, P., (2016). Recent advances in spray drying relevant to the dairy industry: A comprehensive critical review. Dry Technol, 34: 1773-1790.

Shaddel, R., Hesari, J., Azadmard-Damirchi, S., Hamishehkar, H., Fathi-Achachlouei, B., Huang, Q., (2018). Use of gelatin and gum Arabic for encapsulation of black raspberry anthocyanins by complex coacervation. Int J Biol Macromol 107: 1800-1810.

Sharif, H.R., Williams, P.A., Sharif, M.K., Abbas, S., Majeed, H., Masamba, K.G., Safdar, W., Zhong, F., (2018). Current progress in the utilization of native and modified legume proteins as emulsifiers and encapsulants - A review. Food Hydrocoll, 76: 2-16.

Shori, A.B., (2017). Microencapsulation improved probiotics survival during gastric transit. HAYATI J Biosci, 24: 1-5.

Singh, P., Magalhães, S., Alves, L., Antunes, F., Miguel, M., Lindman, B., Medronho, B., (2019). Cellulose-based edible films for probiotic entrapment. Food Hydrocoll, 88: 68-74.

Soccol, C.R., Prado, M.M.R., Garcia, L.M.B., Rodrigues, C., Medeiros, A.B.P., Soccol, V.T., (2014). Current developments in probiotics. J Microb Biochem Technol, 7: 11-20.

Sohail, A., Turner, M.S., Prabawati, E.K., Coombes, A.G.A., Bhandari, B., (2012). Evaluation of Lactobacillus rhamnosus GG and Lactobacillus acidophilus NCFM encapsulated using a novel impinging aerosol method in fruit food products. Int J Food Microbiol, 157: 162-166.

Suganya, V., Anuradha, V., (2017). Microencapsulation and nanoencapsulation: A review. Int J Pharm Clin Res, 9: 233-239. 
Turasan, H., Sahin, S., Sumnu, G., (2015). Encapsulation of rosemary essential oil. LWT Food Sci Technol, 64: 112-119.

Uran, H., Aloğlu, H., Çetin, B., (2017). Probiyotik bakterilerin mikroenkapsülasyonu. Mediterr Agric Sci, 30 (2), 107-112.

Varhan, E., Koç, M., (2018). Gıda bileşenlerinin sprey soğutma yöntemi ile enkapsülasyonu. Food Health, 4(3): 202-212.

Wang, J., Korber, D.R., Low, N.H., Nickerson, M.T., (2014). Entrapment, survival and release of Bifidobacterium adolescentis within chickpea proteinbased microcapsules. Food Res Int, 55: 20-27.

Wang, M., Yang, J., Li, M., Wang, Y., Wu, H., Xiong, L., Sun, Q., (2019). Enhanced viability of layer-by-layer encapsulated Lactobacillus pentosus using chitosan and sodium phytate. Food Chem, 285: 260-265.

Wani, T.A., Shah, A.G., Wani, S.M., Wani, I.A., Masoodi, F.A., Nissar, N., Shagoo, M.A., (2016). Suitability of different food grade materials for the encapsulation of some functional foods well reported for their advantages and susceptibility. Crit Rev Food Sci Nutr, 56(15), 2431-2454.

Zia, K.M., Tabasum, S., Khan, M.F., Akram, N., Akhter, N., Noreen, A., Zuber, M., (2018). Recent trends on gellan gum blends with natural and synthetic polymers: A review. Int J Biol Macromol, 109: 1068-1087. 